Prepared in cooperation with the

New Jersey Department of Environmental Protection

\title{
Sediment Oxygen Demand in the Saddle River and Salem River Watersheds, New Jersey, July-August 2008
}
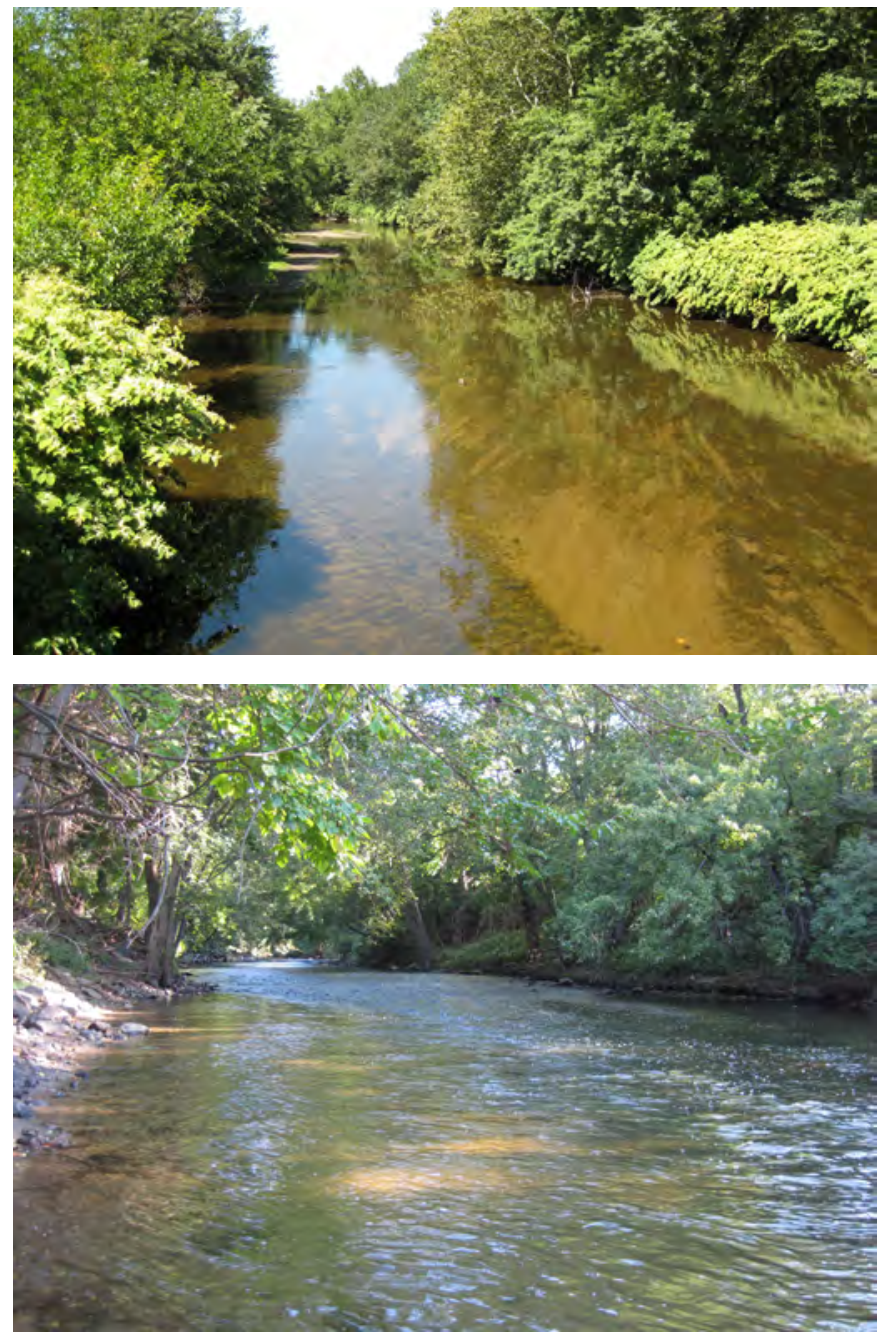
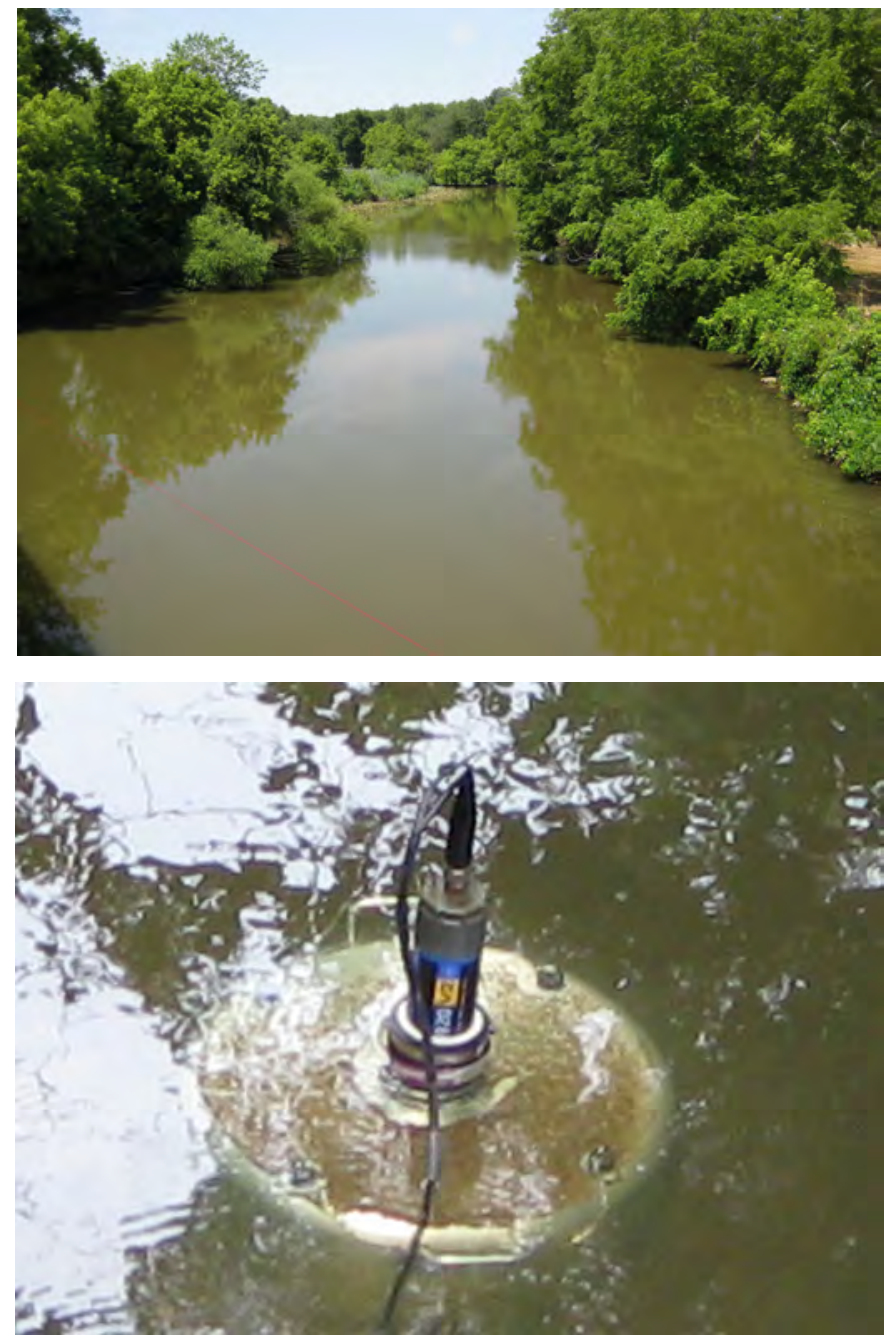

Scientific Investigations Report 2010-5093

U.S. Department of the Interior

U.S. Geological Survey 

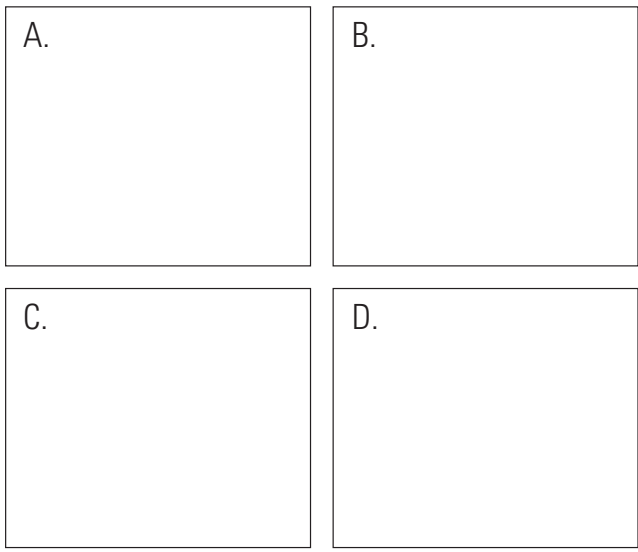

Cover:

A. U.S. Geological Survey station 01391100, Hohokus Brook at mouth at Paramus, New Jersey. (Photograph by H. Heckathorn, U.S. Geological Survey)

B. U.S. Geological Survey station 01482537, Salem River at Courses Landing, New Jersey. (Photograph by H. Heckathorn, U.S. Geological Survey)

C. U.S. Geological Survey station 01391500, Saddle River at Lodi, New Jersey. (Photograph by H. Heckathorn, U.S. Geological Survey)

D. In situ deployment of a sediment oxygen demand chamber equipped with a multiparameter water-quality instrument. (Photograph by J. Gibs, U.S. Geological Survey) 


\section{Sediment Oxygen Demand in the Saddle River and Salem River Watersheds, New Jersey, July-August 2008}

By Heather A. Heckathorn and Jacob Gibs

Prepared in cooperation with the

New Jersey Department of Environmental Protection

Scientific Investigations Report 2010-5093 


\title{
U.S. Department of the Interior \\ KEN SALAZAR, Secretary \\ U.S. Geological Survey \\ Marcia K. McNutt, Director
}

\section{U.S. Geological Survey, Reston, Virginia: 2010}

\begin{abstract}
For more information on the USGS - the Federal source for science about the Earth, its natural and living resources, natural hazards, and the environment, visit http://www.usgs.gov or call 1-888-ASK-USGS.

For an overview of USGS information products, including maps, imagery, and publications, visit http://www.usgs.gov/pubprod

To order this and other USGS information products, visit http://store.usgs.gov
\end{abstract}

\footnotetext{
Any use of trade, product, or firm names is for descriptive purposes only and does not imply endorsement by the U.S. Government. Use of company names is for identification purposes only and does not imply responsibility.

Although this report is in the public domain, permission must be secured from the individual copyright owners to reproduce any copyrighted material contained within this report.

Suggested citation:

Heckathorn, H.A., and Gibs, J., 2010, Sediment oxygen demand in the Saddle River and Salem River watersheds, New Jersey, July-August 2008: U.S. Geological Survey Scientific Investigations Report 2010-5093, 10 p.
} 


\section{Acknowledgments}

The authors gratefully acknowledge Thomas Imbrigiotta of the USGS for help with data collection; James Jelinski of the USGS for manufacturing the chambers; Stewart Rounds of the USGS for technical advice; and Dale Simmons, Kara Watson, and Gregory Simpson of the USGS for editing, illustrations, and report layout. Administrative and technical assistance was provided by Barbara Hirst, Kimberly Cenno, Marzooq Al-Ebus, Patricia Ingelido, and Frank Klapinski of the NJDEP. 



\section{Contents}

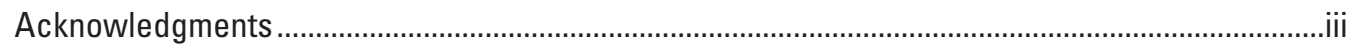

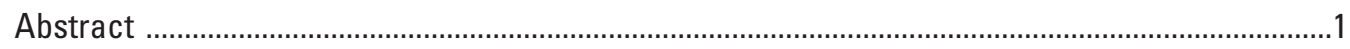

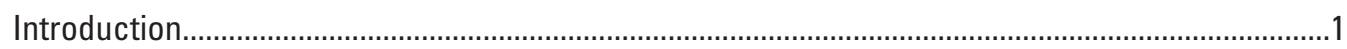

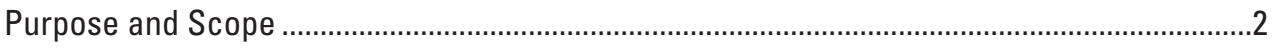

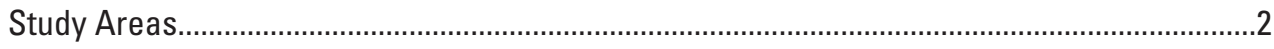

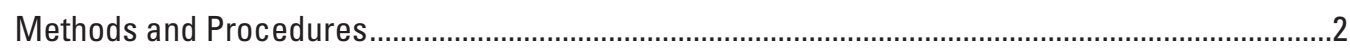

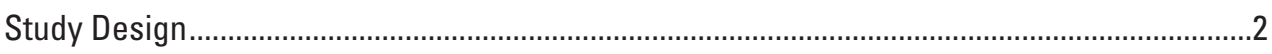

Sediment Oxygen Demand Chambers...................................................................................

Sediment Oxygen Demand Chamber Deployments ..................................................................5

Calculation of Sediment Oxygen Demand .............................................................................6

Sediment Oxygen Demand in the Saddle River and Salem River Watersheds ................................7

Rates of Sediment Oxygen Demand .........................................................................................

Factors Affecting Sediment Oxygen Demand .......................................................................8

Composition of Streambed Material and Streamflow Regime............................................8

Water-Column Oxygen Demand .......................................................................................

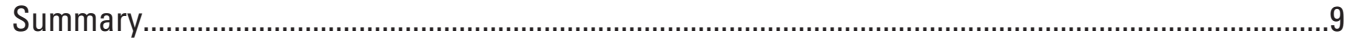

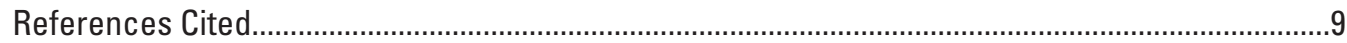




\section{Figures}

1-2. Maps showing-

1. Location of study area, existing water-column water-quality sampling sites, and sediment-oxygen-demand monitoring sites in the Saddle River watershed, NJ

2. Location of study area, existing water-column water-quality sampling sites, and sediment-oxygen-demand monitoring sites in the Salem River watershed, NJ

3. Schematic diagram of sediment-oxygen-demand chamber...........................................5

4. Example graph showing turbidity and dissolved-oxygen depletion curve, showing the typical non-linear initial loss followed by a linear oxygen depletion at Major Run at Sharptown, NJ, on August 6, 2008.

\section{Tables}

1. Site number, site name, and location of sediment-oxygen-demand monitoring sites in the Saddle River and Salem River watersheds, NJ

2. Rates of sediment oxygen demand and water temperature in the Saddle River watershed, NJ.

3. Rates of sediment oxygen demand and water temperature in the Salem River watershed, NJ.

4. Mean total organic carbon concentrations in streambed sediments in the Saddle River and Salem River watersheds, NJ 


\section{Conversion Factors}

\begin{tabular}{lcl}
\hline \multicolumn{1}{c}{ Multiply } & By & \multicolumn{1}{c}{ To obtain } \\
\hline inch (in.) & Length & \\
inch (in.) & 2.54 & centimeter $(\mathrm{cm})$ \\
foot (ft) & 25.4 & millimeter $(\mathrm{mm})$ \\
mile (mi) & 0.3048 & meter $(\mathrm{m})$ \\
\hline & 1.609 & kilometer $(\mathrm{km})$ \\
\hline square foot $\left(\mathrm{ft}^{2}\right)$ & Area & \\
square foot $\left(\mathrm{ft}^{2}\right)$ & 929.0 & square centimeter $\left(\mathrm{cm}^{2}\right)$ \\
square inch $\left(\mathrm{in}^{2}\right)$ & 0.09290 & square meter $\left(\mathrm{m}^{2}\right)$ \\
square mile $\left(\mathrm{mi}^{2}\right)$ & 6.452 & square centimeter $\left(\mathrm{cm}^{2}\right)$ \\
square mile $\left(\mathrm{mi}^{2}\right)$ & 259.0 & hectare $($ ha) \\
\hline & 2.590 & square kilometer $\left(\mathrm{km}^{2}\right)$ \\
\hline quart $(\mathrm{qt})$ & Volume & \\
cubic inch $\left(\mathrm{in}^{3}\right)$ & 0.9464 & liter $(\mathrm{L})$ \\
cubic inch $\left(\mathrm{in}^{3}\right)$ & 16.39 & cubic centimeter $\left(\mathrm{cm}^{3}\right)$ \\
cubic foot $\left(\mathrm{ft}^{3}\right)$ & 0.01639 & liter $(\mathrm{L})$ \\
\hline & 0.02832 & cubic meter $\left(\mathrm{m}^{3}\right)$ \\
\hline foot per second $(\mathrm{ft} / \mathrm{s})$ & Flow rate & \\
cubic foot per second $\left(\mathrm{ft}^{3} / \mathrm{s}\right)$ & 0.3048 & meter per second $(\mathrm{m} / \mathrm{s})$ \\
\hline
\end{tabular}

Temperature in degrees Celsius $\left({ }^{\circ} \mathrm{C}\right)$ may be converted to degrees Fahrenheit $\left({ }^{\circ} \mathrm{F}\right)$ as follows:

$$
{ }^{\circ} \mathrm{F}=\left(1.8 x^{\circ} \mathrm{C}\right)+32
$$

Temperature in degrees Fahrenheit $\left({ }^{\circ} \mathrm{F}\right)$ may be converted to degrees Celsius $\left({ }^{\circ} \mathrm{C}\right)$ as follows:

$$
{ }^{\circ} \mathrm{C}=\left({ }^{\circ} \mathrm{F}-32\right) / 1.8
$$

Horizontal coordinate information is referenced to the North American Datum of 1983 (NAD 83).

Concentrations of chemical constituents in water are given in milligrams per liter (mg/L).

Concentrations of chemical constituents in sediment are given in grams per kilogram (g/kg).

Sediment oxygen demand is given in grams of oxygen per square meter per day $\left(\mathrm{g} / \mathrm{m}^{2} \mathrm{~d}\right)$. 



\title{
Sediment Oxygen Demand in the Saddle River and Salem River Watersheds, New Jersey, July-August 2008
}

\author{
By Heather A. Heckathorn and Jacob Gibs
}

\section{Abstract}

Many factors, such as river depth and velocity, biochemical oxygen demand, and algal productivity, as well as sediment oxygen demand, can affect the concentration of dissolved oxygen in the water column. Measurements of sediment oxygen demand, in conjunction with those of other water-column water-quality constituents, are useful for quantifying the mechanisms that affect in-stream dissolved-oxygen concentrations. Sediment-oxygen-demand rates are also needed to develop and calibrate a water-quality model being developed for the Saddle River and Salem River Basins in New Jersey to predict dissolved-oxygen concentrations. This report documents the methods used to measure sediment oxygen demand in the Saddle River and Salem River watersheds along with the rates of sediment oxygen demand that were obtained during this investigation.

In July and August 2008, sediment oxygen demand was measured in situ in the Saddle River and Salem River watersheds. In the Saddle River Basin, sediment oxygen demand was measured twice at two sites and once at a third location; in the Salem River Basin, sediment oxygen demand was measured three times at two sites and once at a third location.

In situ measurements of sediment oxygen demand in the Saddle River and Salem River watersheds ranged from 0.8 to $1.4 \mathrm{~g} / \mathrm{m}^{2} \mathrm{~d}$ (grams per square meter per day) and from 0.6 to $7.1 \mathrm{~g} / \mathrm{m}^{2} \mathrm{~d}$ at 20 degrees Celsius, respectively. Except at one site in this study, rates of sediment oxygen demand generally were low. The highest rate of sediment oxygen demand measured during this investigation, $7.1 \mathrm{~g} / \mathrm{m}^{2} \mathrm{~d}$, which occurred at Courses Landing in the Salem River Basin, may be attributable to the consumption of oxygen by a large amount of organic matter (54 grams per kilogram as organic carbon) in the streambed sediments or to potential error during data collection. In general, sediment oxygen demand increased with the concentration of organic carbon in the streambed sediments. Repeated measurements made 6 to 7 days apart at the same site locations resulted in similar values.

\section{Introduction}

In accordance with the Federal Clean Water Act, the New Jersey Department of Environmental Protection (NJDEP) identified both the Saddle River below the confluence with
Hohokus Brook in northeastern New Jersey and the Salem River in southwestern New Jersey as exceeding the State's current (2008) Surface-Water-Quality Standard for total phosphorus of $0.1 \mathrm{mg} / \mathrm{L}$ and, therefore, designated these rivers as being impaired with respect to total phosphorus (New Jersey Department of Environmental Protection, 2010). Consequently, the U.S. Geological Survey (USGS), in cooperation with NJDEP, implemented a water-quality monitoring plan for these two unrelated watersheds.

NJDEP may establish a Total Maximum Daily Load (TMDL), the amount of a constituent that a water body can carry and still meet water-quality standards, for phosphorus in these water bodies. One type of impairment of the designated use (Freshwater 2 Nontrout) is excessive primary productivity, which in turn affects the concentration of dissolved oxygen in the water column (New Jersey Department of Environmental Protection, 2009). TMDLs for nutrients commonly are established with the assumption that low concentrations of dissolved oxygen are the result of excessive algal growth, which in turn results from the presence of excessive amounts of nutrients.

Because dissolved oxygen is critical to the health and well-being of aquatic life, environmental officials in the State of New Jersey have established a minimum standard for dissolved oxygen in waterways throughout the State. To fully understand the characteristics of the water bodies, it is essential to quantify the mechanisms that affect concentrations of dissolved oxygen in these water bodies. Understanding a water body's dissolved-oxygen budget requires knowledge of the sinks, as well as the sources, of dissolved oxygen. Many factors, such as river depth and velocity, biochemical oxygen demand, and algal productivity, as well as sediment oxygen demand (SOD), can affect the concentration of dissolved oxygen in the water column. One potentially important sink of dissolved oxygen that was studied in this investigation is SOD, which is the rate at which oxygen is depleted from the water column at or near the streambed sediment-water interface. As organic material settles out of the water column and is decomposed on the streambed, oxygen is consumed, depleting the oxygen that is available for biota. SOD, in conjunction with other water-quality constituents in the water column, is a critical measurement that will be needed to develop and calibrate a water-quality model that can be used by water managers to determine the importance of SOD in water-column dissolvedoxygen concentration and to determine whether a TMDL is needed for the impaired study basins. 


\section{Sediment Oxygen Demand in the Saddle River and Salem River Watersheds, New Jersey, July-August 2008}

\section{Purpose and Scope}

This report documents measurements of SOD made at several locations in the Saddle River and Salem River watersheds. The rate of SOD was measured at three locations in each watershed. In the Saddle River watershed, SOD was measured twice at two sites and once at one additional site. In the Salem River watershed, SOD was measured three times at two sites and once at one additional site. All sampling took place during a period of stable base flow in July and August 2008.

\section{Study Areas}

The Saddle River is a tributary to the Passaic River. The headwaters of the Saddle River are in southeastern New York near the New Jersey-New York border, in the Piedmont physiographic province, in an urban area west of New York City. The Saddle River generally flows from north to south for approximately $12.2 \mathrm{mi}$ to its confluence with Hohokus Brook, and then another $8.2 \mathrm{mi}$ to the mouth of the Saddle River in Garfield, NJ. The drainage area of the Saddle River watershed is $61.0 \mathrm{mi}^{2}$. The study reach on the main stem is relatively slow moving, with a velocity ranging from approximately 0.5 to $1.4 \mathrm{ft} / \mathrm{s}$ during base-flow conditions, and generally has midchannel depths of approximately 2 to $3 \mathrm{ft}$ and a channel width of 60 to $70 \mathrm{ft}$ during base-flow conditions. River discharge is augmented by wastewater-treatment-plant effluent and is reduced by surface-water diversions.

This investigation focuses on the lower part of the Saddle River (fig. 1) and one of its major tributaries, Hohokus Brook. Hohokus Brook receives $18.3 \mathrm{ft}^{3} / \mathrm{s}$ of effluent from two wastewater-treatment plants in urban northeastern New Jersey (Storck and Nawyn, 2001), with a mean annual flow of $36.4 \mathrm{ft}^{3} / \mathrm{s}$ for the period of record (1955-73, 1977-96, and 2006-08) at Hohokus Brook at Ho-Ho-Kus, NJ.

The Salem River watershed (fig. 2) lies in southwestern New Jersey, in the Inner Coastal Plain physiographic province, in a predominantly agricultural area, with the exception of the Borough of Woodstown, which is urban. The streamflow within the watershed is altered by a series of impoundments and agricultural or industrial diversions. One wastewatertreatment plant discharges $0.9 \mathrm{ft}^{3} / \mathrm{s}$ near the headwaters of the Salem River main stem (Zripko and Hasan, 1994). The drainage area of the Salem River watershed is $58.3 \mathrm{mi}^{2}$. The Salem River generally flows westward and is a tributary to the Delaware River. The headwaters of the Salem River are a series of six lakes. After the downstream-most lake, Memorial Lake, in Woodstown, the stream's velocity ranges from approximately 0.1 to $0.6 \mathrm{ft} / \mathrm{s}$ during base-flow conditions, mid-channel depths are approximately $1.5 \mathrm{ft}$, and channel width ranges from 20 to $50 \mathrm{ft}$ for approximately $4.1 \mathrm{mi}$ until it approaches Courses Landing.

Approximately 1.5 river miles upstream from Courses Landing and continuing throughout the downstream portions of the watershed, the river broadens and deepens, behaving more like a reservoir than a free-flowing stream for approximately $8.3 \mathrm{mi}$, with mid-channel depths of approximately 6 to $8 \mathrm{ft}$ and a channel width of nearly $150 \mathrm{ft}$ along this reach at base-flow conditions. Stream velocities in this reach are extremely slow, approximately $0.03 \mathrm{ft} / \mathrm{s}$, and nearly immeasurable. SOD monitoring in the Salem River watershed was focused on the upper portion of the watershed, from just below Memorial Lake to Courses Landing.

\section{Methods and Procedures}

The methods and procedures used in this investigation are reported below. These include the study design, sedimentoxygen-demand-chamber design and deployment, and the calculations involved in reporting sediment oxygen demand.

\section{Study Design}

Site selection was based on field reconnaissance in each of the targeted watersheds. Because the downstream reaches of the Salem River are deep and diving teams were not an available option to deploy chambers, site selection focused on the upper reaches of the watershed. To aid the planned water-quality modeling of the watershed, it was decided to deploy SOD chambers at existing water-column water-quality sampling sites. The chamber was deployed at one location per site where the streambed material and stream mixing were representative of the entire stream reach, and where it was possible to wade to the center of the channel. Because it was impossible to wade to the center of the Salem River channel at Courses Landing, chamber deployment at this site occurred at the only location that was accessible without diving.

Three sites in each watershed were chosen for SOD measurement (table 1). In the Saddle River watershed, two sites were on the main stem and one site was on Hohokus Brook, a tributary, just upstream from its confluence with Saddle River (fig. 1). The sites in the Salem River watershed included two on the main stem and one on a tributary, Major Run (fig. 2).

One chamber was deployed two to three times within a 6- to 12-day period at each monitoring site. Multiple deployments, spaced 6 to 7 days apart, at each site provided additional data to test for reproducibility of the SOD data.

\section{Sediment Oxygen Demand Chambers}

The SOD chambers and procedures for deployment and collection of data were modifications of those used by the USGS in previous studies conducted in Oregon (Doyle and Lynch, 2005; Doyle and Rounds, 2003; Wood, 2001; Rounds and Doyle, 1997). The chambers used in this study were open-bottom, aluminum cylinders designed to seat and seal in the streambed sediments. A multiparameter instrument 


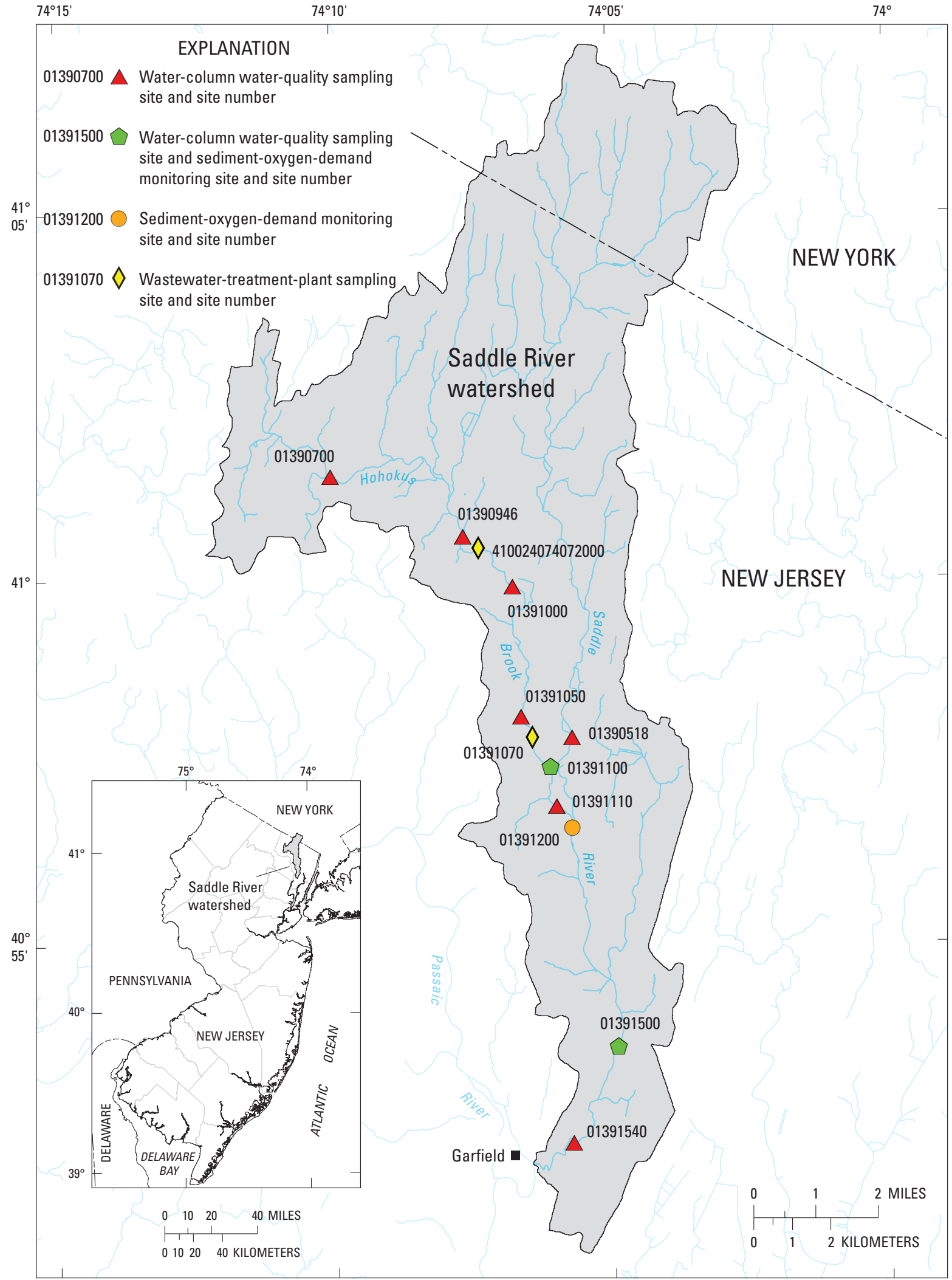

Figure 1. Location of study area, existing water-column water-quality sampling sites, and sediment-oxygen-demand monitoring sites in the Saddle River watershed, NJ. 


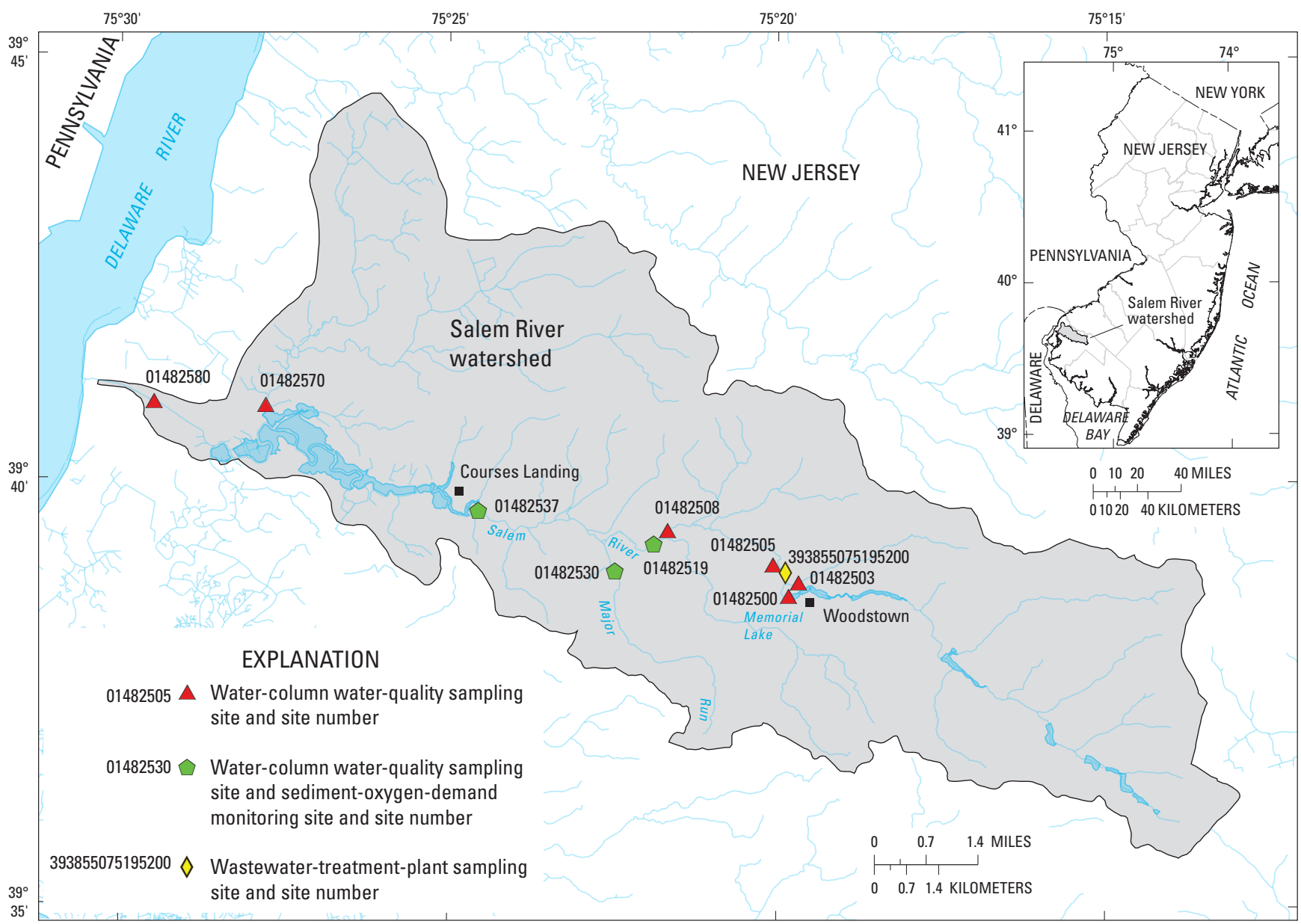

Figure 2. Location of study area, existing water-column water-quality sampling sites, and sediment-oxygen-demand monitoring sites in the Salem River watershed, NJ.

Table 1. Site number, site name, and location of sediment-oxygen-demand monitoring sites in the Saddle River and Salem River watersheds, NJ.

\begin{tabular}{|c|c|c|c|}
\hline $\begin{array}{l}\text { U.S. Geological } \\
\text { Survey site } \\
\text { number }\end{array}$ & Site name & Latitude & Longitude \\
\hline \multicolumn{4}{|c|}{ Saddle River watershed } \\
\hline 01391100 & Hohokus Brook at mouth at Paramus, NJ & $40^{\circ} 57^{\prime} 19^{\prime \prime}$ & $074^{\circ} 06^{\prime} 02^{\prime \prime}$ \\
\hline 01391200 & Saddle River at Fair Lawn, NJ & $40^{\circ} 56^{\prime} 29^{\prime \prime}$ & $074^{\circ} 05^{\prime} 39^{\prime \prime}$ \\
\hline 01391500 & Saddle River at Lodi, NJ & $40^{\circ} 53^{\prime} 25^{\prime \prime}$ & $074^{\circ} 04^{\prime} 50^{\prime \prime}$ \\
\hline \multicolumn{4}{|c|}{ Salem River watershed } \\
\hline 01482519 & Salem River at Main Street, at Sharptown, NJ & $39^{\circ} 39^{\prime} 15^{\prime \prime}$ & $075^{\circ} 21^{\prime} 52^{\prime \prime}$ \\
\hline 01482530 & Major Run at Sharptown, NJ & $39^{\circ} 38^{\prime} 56^{\prime \prime}$ & $075^{\circ} 22^{\prime} 28^{\prime \prime}$ \\
\hline 01482537 & Salem River at Courses Landing, NJ & $39^{\circ} 39^{\prime} 38^{\prime \prime}$ & $075^{\circ} 24^{\prime} 33^{\prime \prime}$ \\
\hline
\end{tabular}


(YSI model $6920 \mathrm{~V} 2$, in this case) installed in the center of each chamber was equipped with sensors for water temperature, specific conductance, turbidity (YSI model 6136), and dissolved oxygen (YSI model 6150 ROX). The instrument was mounted vertically in the chamber inside a schedule 40 , 3-in.-diameter aluminum pipe and was sealed for an airtight connection.

The chambers used in this study were not equipped with recirculating pumps because the dissolved-oxygen sensor was not affected by a minimum water velocity. In addition, it was thought that devising a way to deliver power to the mixing device within the chamber would compromise the gas- and water-tight seal of the chamber, which would have compromised the data.

A schematic diagram of the chamber is shown in figure 3. The area covered by the chamber and the inside volume of the chamber are $312 \mathrm{in}^{2}\left(0.2013 \mathrm{~m}^{2}\right)$ and 2,594 $\mathrm{in}^{3}\left(0.0425 \mathrm{~m}^{3}\right)$, respectively, corrected for the volume of the chamber's bottom edges, which were submerged approximately $1.25 \mathrm{in}$. in the streambed, plus the volume occupied by the water-quality sensors $\left(411 \mathrm{in}^{3}\right.$, or $\left.0.006735 \mathrm{~m}^{3}\right)$.

\section{Sediment Oxygen Demand Chamber Deployments}

SOD chambers were deployed in July and August 2008 during stable, base-flow conditions. Water temperatures ranged from 19 to $23^{\circ} \mathrm{C}$ and 18 to $27^{\circ} \mathrm{C}$ in the Saddle River and Salem River Basins, respectively, during this investigation; dissolved-oxygen readings for sites in the Saddle River and Salem River Basins ranged from 68 to 143 and 32 to 118 percent of dissolved-oxygen saturation, respectively, during this investigation. The chambers were deployed long enough to observe a depletion of at least $1 \mathrm{mg} / \mathrm{L}$ of dissolved oxygen inside the chamber.

Two SOD-monitoring sites in the Saddle River watershed had two deployments, spaced 7 days apart, of one SOD

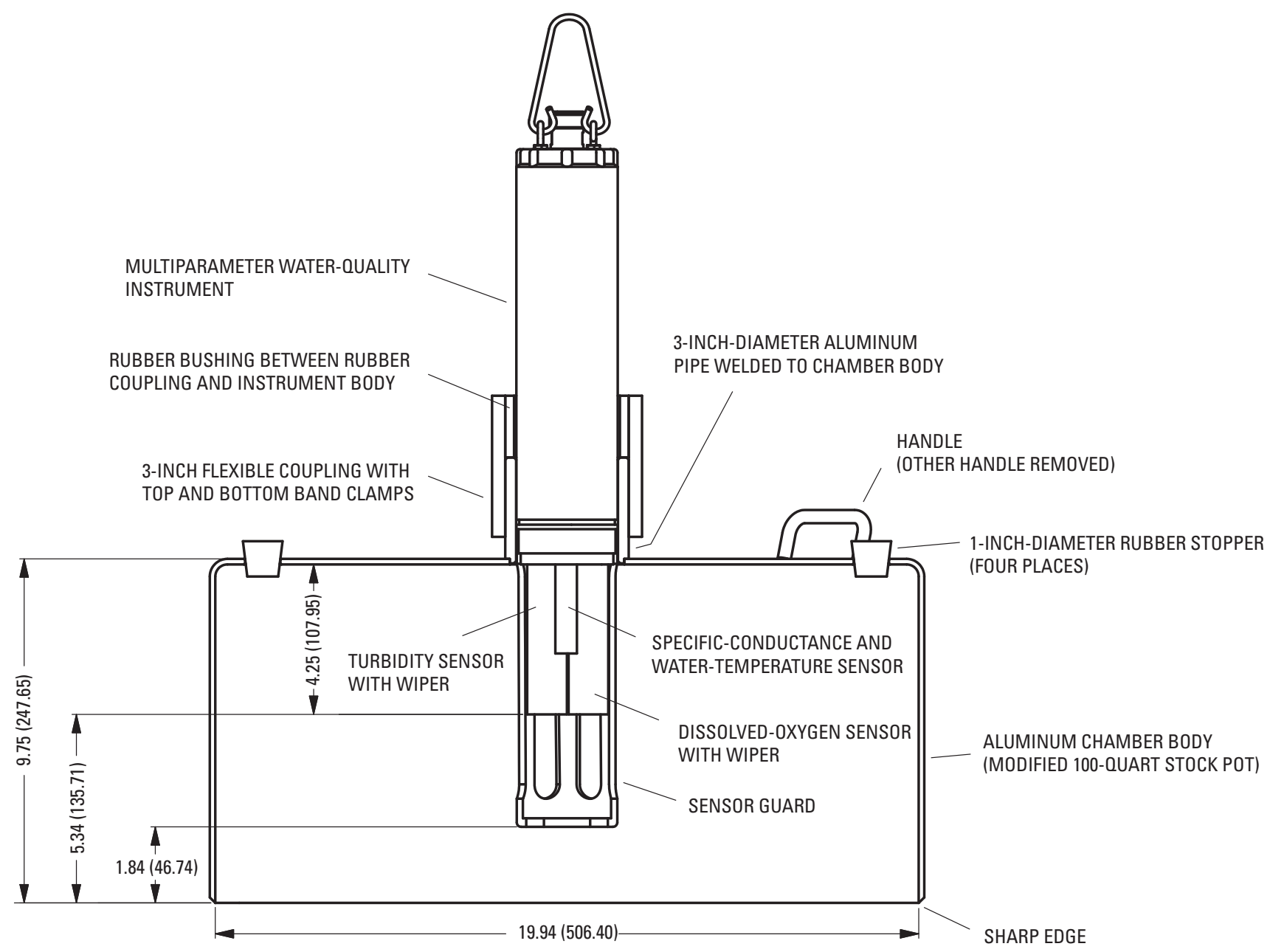

Figure 3. Schematic diagram of sediment-oxygen-demand chamber. (Modified from J.C. Jelinski, U.S. Geological Survey, written commun., 2009; measurements are given in inches; measurements in parentheses are in millimeters.) 


\section{Sediment 0xygen Demand in the Saddle River and Salem River Watersheds, New Jersey, July-August 2008}

chamber per visit. The third SOD-monitoring site in the Saddle River Basin had one deployment of one SOD chamber. Two sites in the Salem River watershed had three deployments, spaced 6 days apart, of one chamber per visit; the third site in the Salem River Basin had one deployment of one chamber. Sites were selected from existing water-column sampling locations in the Saddle River and Salem River watersheds (figs. 1 and 2) by satisfying the following criteria:

1. a minimum stream depth of 10 in. during base-flow conditions so that the top of the chamber was fully submerged,

2. streambed sediments that permit the bottom edge of the chamber to be submerged to a minimum depth of 1 in. to effectively seal the streamwater inside the chamber, and

3. historical DO data and other water-quality data indicating probable large swings in diurnal DO or not meeting the in-stream standard for DO.

A multiparameter instrument was used for the chamber measurements and was programmed to electronically record measurements of water temperature, specific conductance, dissolved oxygen, and turbidity at 3-minute intervals. The wipers on the optical sensors, for turbidity and dissolved oxygen, were programmed to sequentially wipe each sensor three times before each measurement. There were no concentration gradients caused by the water-quality instrumentation because, unlike a polarographic dissolved-oxygen sensor, the optical DO sensor does not consume oxygen (Yellow Springs Instruments Inc., 2006).
The calibrated multiparameter water-quality instrument was installed in the chamber upon arrival at the SOD-monitoring site. All deployments in this study were accomplished by wading. A hand-held display unit was connected to the instrument using a data-transmission cable. With the ports in the top of the chamber open to allow air to escape when the chamber was submerged, the chamber with the multiparameter instrument was carried into the stream. The chamber was maneuvered to allow any trapped air to escape through the ports, and was gently seated so the bottom edge penetrated the streambed sediments to a depth of approximately $1.25 \mathrm{in}$. The four ports in the top of the chamber then were closed with rubber stoppers. The data acquired were monitored from the hand-held display on the streambank. When a decrease in dissolvedoxygen concentration of at least $1 \mathrm{mg} / \mathrm{L}$ was observed, the measurement of SOD was deemed to be complete. The SOD measurement generally occurred over a span of approximately 5 to 6 hours. Post-calibration checks were performed on the multiparameter instrument after the chamber was retrieved. Post-calibration checks showed minimal instrument drift or fouling and, therefore, the instrument was not a source of error.

\section{Calculation of Sediment Oxygen Demand}

The SOD rate was calculated using two methods. In both methods, the typical, nonlinear decrease in dissolved-oxygen concentration during the first several minutes or, sometimes, hour of the chamber deployment while turbidity was decreasing was disregarded (fig. 4). In previous investigations, this

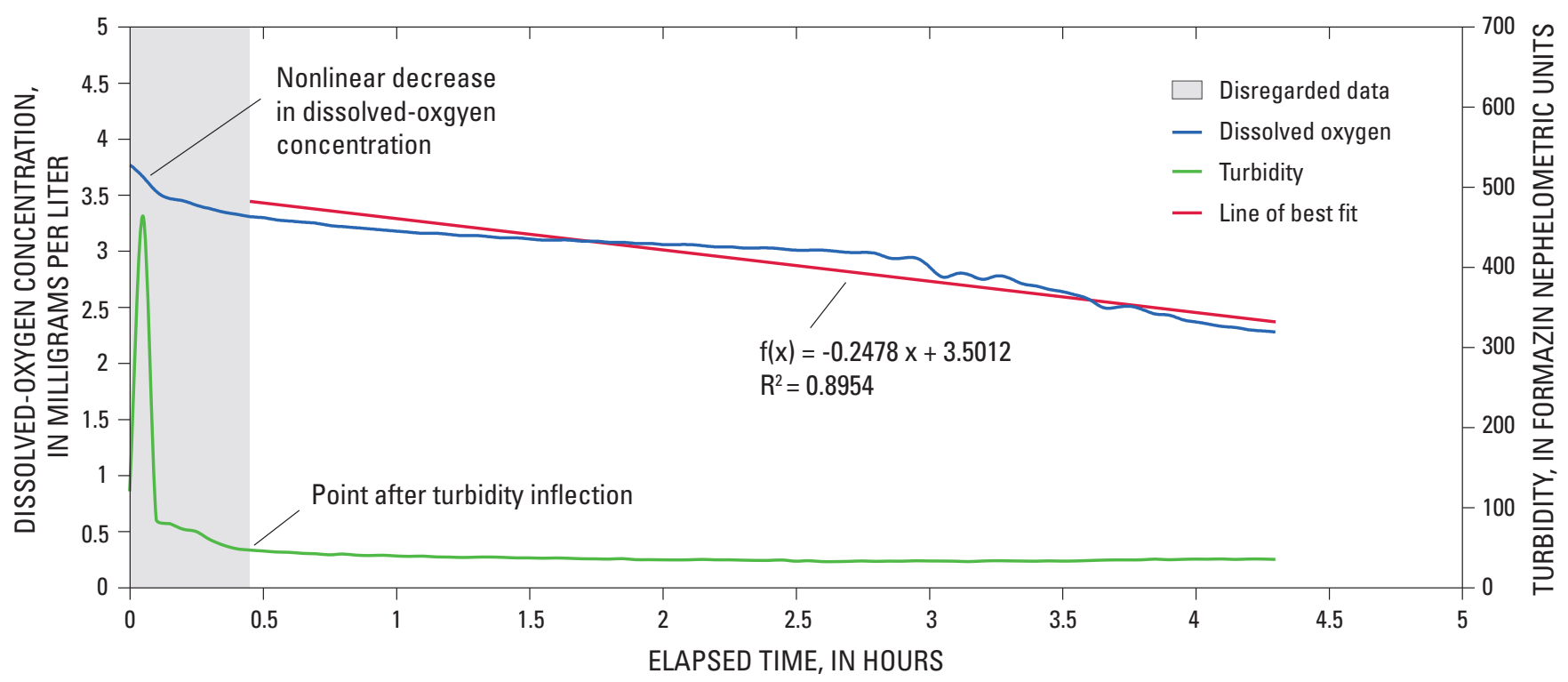

Figure 4. Example graph showing turbidity and dissolved-oxygen depletion curve, showing the typical non-linear initial loss followed by a linear oxygen depletion at Major Run at Sharptown, NJ, on August 6, 2008. 
nonlinear decrease in dissolved-oxygen concentration has been attributed to the suspension of streambed sediments in the water column for a period of time until the sediments settled back to the sediment surface (Rounds and Doyle, 1997). After the rate of change of turbidity reached a constant, the SOD rate was assumed to be representative of the SOD at the monitoring site and not caused by any suspension of sediments that occurred during the installation of the chamber.

In the first method, dissolved-oxygen concentrations were plotted on a graph as a function of elapsed time, resulting in a dissolved-oxygen depletion curve. The slope of the linear part of the oxygen-depletion curve was determined through linear regression and used to calculate the SOD rate:

$$
S_{T}=1.44(V / A) \mathrm{b},
$$

where $\mathrm{SOD}_{\mathrm{T}}$ is the sediment oxygen demand rate, in grams per square meter per day, at water temperature $\mathrm{T} ; \mathrm{V}$ is the volume of water in the chamber, in liters; $\mathrm{A}$ is the area of the streambed sediment covered by the chamber, in square meters; $b$ is the slope of the oxygen-depletion curve, in milligrams per liter per minute; and 1.44 is a units-conversion constant.

SOD rates were corrected to $20^{\circ} \mathrm{C}$ using a standard van't Hoff equation:

$$
S O D_{20}=S O D_{T} / 1.065^{(T-20)},
$$

where $\mathrm{SOD}_{20}$ is the sediment oxygen demand rate, in grams per square meter per day, at $20^{\circ} \mathrm{C}$ and $\mathrm{T}$ is the water temperature, in degrees Celsius (Thomann and Mueller, 1987). Although this correction does not hold true for water temperatures less than $10^{\circ} \mathrm{C}$ (Rounds and Doyle, 1997), water temperatures in the Saddle and Salem River watersheds in this study ranged from 19 to $23^{\circ} \mathrm{C}$ and 18 to $27^{\circ} \mathrm{C}$, respectively.

In the second method, because the dissolved-oxygen concentration was recorded every 3 minutes, SOD rates also could be calculated every 3 minutes, using the above equations; these calculations result in an average $\mathrm{SOD}_{\mathrm{T}}$ and $\mathrm{SOD}_{20}$ over an interval of time.

\section{Sediment Oxygen Demand in the Saddle River and Salem River Watersheds}

SOD measurements at Saddle River and Salem River mainstem locations as well as at locations on selected tributaries are documented in this section. Rates of SOD and factors affecting them are also discussed.

\section{Rates of Sediment Oxygen Demand}

Using the slope of the oxygen-depletion curve to calculate SOD, $\mathrm{SOD}_{20}$ in the Saddle River watershed ranged from 0.8 to $1.4 \mathrm{~g} / \mathrm{m}^{2} \mathrm{~d}$ on the main stem and tributary (table 2).

Using the same method to calculate $\mathrm{SOD}, \mathrm{SOD}_{20}$ in the Salem River watershed ranged from 0.6 to $2.0 \mathrm{~g} / \mathrm{m}^{2} \mathrm{~d}$, with the exception of a value of $7.1 \mathrm{~g} / \mathrm{m}^{2} \mathrm{~d}$ at Salem River at Courses Landing (table 3).

This investigation included a site on the Salem River at Main Street in Sharptown, which is within 0.3 river mi of Site 2 in a previous study by Najarian Associates (Litwack and Najarian, 1990). The $\mathrm{SOD}_{20}$ results for this site in this study and in the study by Najarian Associates in 1989 are both low. The median $\mathrm{SOD}_{20}$ in this investigation was $1.0 \mathrm{~g} / \mathrm{m}^{2} \mathrm{~d}$, whereas the median value in the Najarian Associates study was $2.03 \mathrm{~g} / \mathrm{m}^{2} \mathrm{~d}$ (Litwack and Najarian, 1990).

Differences in these results may stem partly from the fact that Najarian Associates measured SOD using the laboratory method, whereas in this study, SOD was measured using an in situ method. The in situ technique is a direct measurement of SOD that is made in the field under ambient conditions, whereas the laboratory technique involves coring streambed sediments for later measurement of oxygen depletion in a controlled setting (Bowman and Delfino, 1979). Although each technique has advantages and disadvantages, the in situ method was used in this study because it does not disturb ambient conditions, streambed sediments, or aquatic biota during measurement.

Table 2. Rates of sediment oxygen demand and water temperature in the Saddle River watershed, NJ.

[Data are available at the U.S. Geological Survey, NJ Water Science Center in West Trenton, NJ; deg C, degrees Celsius; SOD , rate of sediment oxygen demand at river-water temperature; $\mathrm{SOD}_{20}$, rate of sediment oxygen demand corrected to 20 degrees Celsius; $\mathrm{g} / \mathrm{m}^{2} \mathrm{~d}$, grams of oxygen per square

\begin{tabular}{|c|c|c|c|c|c|c|c|}
\hline \multirow{2}{*}{$\begin{array}{l}\text { U.S. Geological } \\
\text { Survey site } \\
\text { number }\end{array}$} & \multirow[b]{2}{*}{ Site name } & \multirow[b]{2}{*}{ Date } & \multirow{2}{*}{$\begin{array}{c}\text { Water } \\
\text { temperature } \\
(\operatorname{deg} C)\end{array}$} & \multicolumn{2}{|c|}{ Linear-regression method } & \multicolumn{2}{|c|}{ Three-minute method } \\
\hline & & & & $\underset{\left(g / m^{2} d\right)}{S O D_{T}}$ & $\begin{array}{l}\operatorname{SOD}_{20} \\
\left(g / m^{2} d\right)\end{array}$ & $\underset{\left(g / m^{2} d\right)}{\operatorname{SOD}_{T}}$ & $\begin{array}{l}\operatorname{SOD}_{20} \\
\left(g / m^{2} d\right)\end{array}$ \\
\hline \multirow[t]{2}{*}{01391100} & \multirow{2}{*}{$\begin{array}{l}\text { Hohokus Brook at mouth at } \\
\text { Paramus, NJ }\end{array}$} & $8 / 20 / 2008$ & 22.0 & 0.9 & 0.8 & 1.3 & 1.2 \\
\hline & & $8 / 27 / 2008$ & 21.5 & 1.3 & 1.2 & 1.5 & 1.4 \\
\hline 01391200 & Saddle River at Fair Lawn, NJ & $8 / 20 / 2008$ & 20.6 & 1.4 & 1.4 & 1.3 & 1.3 \\
\hline \multirow[t]{2}{*}{01391500} & Saddle River at Lodi, NJ & $8 / 20 / 2008$ & 22.1 & 1.5 & 1.4 & 1.7 & 1.5 \\
\hline & & $8 / 27 / 2008$ & 20.4 & 1.4 & 1.4 & 1.1 & 1.0 \\
\hline
\end{tabular}
meter per day] 


\section{Sediment Oxygen Demand in the Saddle River and Salem River Watersheds, New Jersey, July-August 2008}

Table 3. Rates of sediment oxygen demand and water temperature in the Salem River watershed, NJ.

[Data are available at the U.S. Geological Survey, NJ Water Science Center in West Trenton, NJ; deg C, degrees Celsius; $\mathrm{SOD}_{\mathrm{T}}$, rate of sediment oxygen demand at river-water temperature; $\mathrm{SOD}_{20}$, rate of sediment oxygen demand corrected to 20 degrees Celsius; $\mathrm{g} / \mathrm{m}^{2} \mathrm{~d}$, grams of oxygen per square meter per day]

\begin{tabular}{|c|c|c|c|c|c|c|c|}
\hline \multirow{2}{*}{$\begin{array}{l}\text { U.S. Geological } \\
\text { Survey site } \\
\text { number }\end{array}$} & \multirow[b]{2}{*}{ Site name } & \multirow[b]{2}{*}{ Date } & \multirow{2}{*}{$\begin{array}{c}\text { Water } \\
\text { temperature } \\
(\operatorname{deg} C)\end{array}$} & \multicolumn{2}{|c|}{ Linear-regression method } & \multicolumn{2}{|c|}{ Three-minute method } \\
\hline & & & & $\begin{array}{l}\operatorname{SOD}_{\mathrm{T}} \\
\left(\mathrm{g} / \mathrm{m}^{2} \mathrm{~d}\right)\end{array}$ & $\begin{array}{l}\operatorname{SOD}_{20} \\
\left(\mathrm{~g} / \mathrm{m}^{2} d\right)\end{array}$ & $\begin{array}{l}\operatorname{SOD}_{\mathrm{T}} \\
\left(\mathrm{g} / \mathrm{m}^{2} \mathrm{~d}\right)\end{array}$ & $\begin{array}{l}\mathrm{SOD}_{20} \\
\left(\mathrm{~g} / \mathrm{m}^{2} \mathrm{~d}\right)\end{array}$ \\
\hline \multirow[t]{3}{*}{01482519} & \multirow{3}{*}{$\begin{array}{l}\text { Salem River at Main Street, at } \\
\text { Sharptown, NJ }\end{array}$} & $7 / 31 / 2008$ & 24.0 & 0.8 & 0.6 & 1.0 & 0.8 \\
\hline & & $8 / 06 / 2008$ & 22.9 & 1.2 & 1.0 & 1.2 & 1.0 \\
\hline & & $8 / 12 / 2008$ & 20.4 & 1.2 & 1.1 & 1.2 & 1.1 \\
\hline \multirow[t]{3}{*}{01482530} & Major Run at Sharptown, NJ & $7 / 31 / 2008$ & 26.0 & 3.0 & 2.0 & 3.0 & 2.1 \\
\hline & & $8 / 06 / 2008$ & 25.9 & 1.4 & 1.0 & 1.5 & 1.0 \\
\hline & & $8 / 12 / 2008$ & 21.3 & 1.5 & 1.4 & 1.8 & 1.6 \\
\hline 01482537 & Salem River at Courses Landing, NJ & $8 / 06 / 2008$ & 26.4 & 10.5 & 7.1 & 11.6 & 7.8 \\
\hline
\end{tabular}

To determine the variability of the results and the precision of the measurements, and because measurements were replicated, albeit 6 to 7 days apart, relative percent difference was calculated using $10 \mathrm{SOD}_{20}$ results that were determined by the linear regression method. The average of the relative percent differences was 18 percent for all deployments in the Saddle and Salem Rivers.

\section{Factors Affecting Sediment Oxygen Demand}

Factors affecting sediment oxygen demand are discussed below. Likely factors affecting SOD, such as the chemical and biological composition of the streambed materials and watercolumn oxygen demand, are discussed.

\section{Composition of Streambed Material and Streamflow Regime}

The rates of oxygen depletion at the sediment-water interface vary, possibly depending on the composition of streambed material. Streambed sediments at sampling locations in the Saddle River watershed are primarily sand or gravel, whereas those at sites in the Salem River watershed are composed of silt and organic material. In both watersheds, the rates of SOD seem to track the total carbon content of streambed sediments. The carbon in the streambed sediments was predominantly organic carbon in both watersheds. The mean concentration of organic carbon in streambed sediment from nine locations in the Saddle River watershed was $2.5 \mathrm{~g} / \mathrm{kg}$ (table 4). The mean concentration of organic carbon in streambed sediments from six locations in the Salem River watershed upstream from Courses Landing was $4.0 \mathrm{~g} / \mathrm{kg}$, whereas the mean concentration of organic carbon in streambed sediments at Salem River at Courses Landing was $54 \mathrm{~g} / \mathrm{kg}$ (table 4). (These data are stored in the USGS National Water Information System (NWIS) database available at the USGS
Web site http://waterdata.usgs.gov/nj/nwis.) The SOD rate at Courses Landing was much greater than the rates calculated for upstream portions of the watershed.

Additionally, the Courses Landing site lies in the reservoir-like reach of the Salem River, where the river's mean velocity is $0.04 \mathrm{ft} / \mathrm{s}$ during base-flow conditions (U.S. Geological Survey, 2009). The reach at Courses Landing is an area of sediment deposition; in a span of 3 river miles, the cross-sectional area of the channel increases from approximately $50 \mathrm{ft}^{2}$ at Salem River at Main Street at Sharptown to approximately $500 \mathrm{ft}^{2}$ at Salem River at Courses Landing as a result of the presence of downstream dams. The slow velocities in the pooled section of the river allow a large amount of organic material to settle to the stream bottom, where it can decompose and increase the rate of oxygen depletion. Aerobic decomposition of the organic carbon in the streambed sediments at the streambed sediment-water interface consumes oxygen and, therefore, affects the rate of oxygen depletion. It is also possible, however, that the organic matter at the Courses Landing site could be oxidized through chemical and physical processes that consume oxygen. Sediments in the pooled reach of the river are likely more susceptible to decomposition, and consequently demand more oxygen, than the organic matter in the upstream reaches of the watershed.

The streambed material in the wadeable sections at Salem River at Courses Landing is primarily a thin layer of organic matter underlain by construction debris that may have prevented the chamber from being completely sealed on the streambed, resulting in a high rate of SOD. For these reasons, along with the inability to wade to a suitable location for chamber deployment due to stream depths, the in situ measurement of SOD was not repeated at Salem River at Courses Landing. 
Table 4. Mean total organic-carbon concentrations in streambed sediments in the Saddle River and Salem River watersheds, NJ.

\begin{tabular}{|c|c|c|}
\hline $\begin{array}{l}\text { U.S. Geological } \\
\text { Survey site } \\
\text { number }\end{array}$ & Site name & $\begin{array}{l}\text { Mean total organic- } \\
\text { carbon concentration } \\
\text { (grams per kilogram) }\end{array}$ \\
\hline \multicolumn{3}{|c|}{ Saddle River watershed } \\
\hline 01390518 & Saddle River at Grove Street, at Ridgewood & 0.6 \\
\hline 01390700 & Hohokus Brook at Wyckoff, NJ & 2.2 \\
\hline 01390946 & Hohokus Brook at Waldwick Avenue, at Waldwick, NJ & 4.9 \\
\hline 01391000 & Hohokus Brook at Ho-Ho-Kus, NJ & 3.2 \\
\hline 01391050 & Hohokus Brook at Grove Street, at Ridgewood, NJ & 2.7 \\
\hline 01391100 & Hohokus Brook at mouth at Paramus, NJ & 3.1 \\
\hline 01391110 & Saddle River at Paramus & 1.6 \\
\hline 01391500 & Saddle River at Lodi, NJ & 1.3 \\
\hline 01391540 & Saddle River at Felician College footbridge, at Lodi, NJ & 3.3 \\
\hline \multicolumn{3}{|c|}{ Salem River watershed } \\
\hline 01482500 & Salem River at Woodstown, NJ & 3.6 \\
\hline 01482503 & Chestnut Run at Woodstown, NJ & 2.7 \\
\hline 01482505 & Salem River at Rt-40, at Woodstown, NJ & 3.8 \\
\hline 01482508 & Salem River at Rt-40, at Sharptown, NJ & 3.8 \\
\hline 01482519 & Salem River at Main Street, at Sharptown, NJ & 7.4 \\
\hline 01482530 & Major Run at Sharptown, NJ & 2.7 \\
\hline 01482537 & Salem River at Courses Landing, NJ & 54 \\
\hline
\end{tabular}

\section{Water-Column Oxygen Demand}

Water-column samples from the Salem River watershed were analyzed for 5-day carbonaceous biochemical oxygen demand $\left(\mathrm{CBOD}_{5}\right)$ as part of a broader water-column waterquality study co-occurring with this investigation. The $\mathrm{CBOD}_{5}$ for those samples was relatively low (generally less than $2 \mathrm{mg} / \mathrm{L}$ during base-flow conditions) in this study; historical data (from November 1997 to November 2002) for the Saddle River watershed generally also show low concentrations (median less than $3 \mathrm{mg} / \mathrm{L}$ ) of 5-day biochemical oxygen demand $\left(\mathrm{BOD}_{5}\right)$ during base-flow conditions. For $\mathrm{CBOD}_{5}$ results near the reporting level of $2 \mathrm{mg} / \mathrm{L}$ and a measurement of $3 \mathrm{mg} / \mathrm{L}$, the variability of the measurement of $\mathrm{CBOD}_{5}$ is very large, with relative standard deviations of 46 and 38 percent, respectively (American Public Health Association, American Water Works Association, and Water Environment Federation, 1998). Given the low water-column biochemical oxygen demand in the Saddle River and Salem River watersheds and the relatively poor precision of the analysis of $\mathrm{CBOD}_{5}$ at low $\mathrm{CBOD}_{5}$ concentrations in the study areas, water-column oxygen demand blanks may introduce a large error in determining SOD.

\section{Summary}

Along with river depth and velocity, biochemical oxygen demand, and algal productivity, SOD is one factor that can alter the water-column dissolved-oxygen concentration. Therefore, the USGS, in cooperation with the NJDEP, measured SOD rates using in situ techniques at three sites on the main stems and tributaries of the Saddle and Salem Rivers. $\mathrm{SOD}_{20}$ ranged from 0.8 to $1.4 \mathrm{~g} / \mathrm{m}^{2} \mathrm{~d}$ in the Saddle River watershed and from 0.6 to $2.0 \mathrm{~g} / \mathrm{m}^{2} \mathrm{~d}$ in the Salem River watershed, with the exception of a measurement of $7.1 \mathrm{~g} / \mathrm{m}^{2} \mathrm{~d}$ at Salem River at Courses Landing. The high rate of SOD that was measured at Courses Landing may have resulted from high concentrations of organic carbon $(54 \mathrm{~g} / \mathrm{kg})$ in the streambed sediments. In general, sediment oxygen demand increased with the organiccarbon content of the streambed sediments.

\section{References Cited}

American Public Health Association, American Water Works Association, and Water Environment Federation, 1998, Standard methods for the examination of water and wastewater (20th ed.): Baltimore, MD, American Public Health Association, p. 5-2-5-6. 
Bowman, G.T., and Delfino, J.J., 1979, Sediment oxygen demand techniques: A review and comparison of laboratory and in-situ systems: Water Research, v. 14, p. 491-499.

Doyle, M.C., and Lynch, D.D., 2005, Sediment oxygen demand in Lake Ewauna and the Klamath River, Oregon, June 2003: U.S. Geological Survey Scientific Investigations Report 05-5228, 14 p.

Doyle, M.C., and Rounds, S.A., 2003, The effect of chamber mixing velocity on bias in measurement of sediment oxygen demand rates in the Tualatin River, Oregon: U.S. Geological Survey Water-Resources Investigations Report 03-4097, $16 \mathrm{p}$.

Litwack, H.S., and Najarian, T.O., 1990, Impact analysis of a wastewater discharge on the water quality of the Salem River: West Eatontown, NJ, Najarian Associates, L.P., Final Project Report, April 1990, 133 p.

New Jersey Department of Environmental Protection, 2010, Surface water quality standards: New Jersey Department of Environmental Protection, N.J.A.C 7:9B, accessed February 25, 2010, at http://www.nj.gov/dep/rules/rules/ njac7_9b.pdf.

New Jersey Department of Environmental Protection, 2009, New Jersey integrated water quality monitoring and assessment report, Appendix A, accessed February 25, 2010, at http://www.state.nj.us/dep/wms/bwqsa/2008_revised_final_ Integrated_List.pdf.

Rounds, S.A., and Doyle, M.C., 1997, Sediment oxygen demand in the Tualatin River Basin, Oregon, 1992-96: U.S. Geological Survey Water-Resources Investigations Report 97-4103, 19 p.

Storck, D.A., and Nawyn, J.P., 2001, Reconstruction of streamflow records in the Passaic and Hackensack River basins, New Jersey and New York, water years 1993-96: U.S. Geological Survey Water-Resources Investigations Report 01-4078, 89 p.

Thomann, R.V., and Mueller, J.A., 1987, Principles of surface water quality modeling and control: New York, Harper and Rowe, p. 291-293.

U.S. Geological Survey, 2009, National Water Information System: Web interface, accessed June 26, 2009, at http:// waterdata.usgs.gov/nj/nwis/.

Wood, T.M., 2001, Sediment oxygen demand in Upper Klamath and Agency Lakes, Oregon, 1999: U.S. Geological Survey Water-Resources Investigations Report 01-4080, 13 p.

Yellow Springs Instruments Inc., 2006, Operating manual for YSI 6-series environmental monitoring systems, $324 \mathrm{p}$., accessed July 6, 2009, at http://www.ysi.com/medial pdfs/069300-YSI-6-Series-Manual-RevF.pdf.
Zripko, N.P., and Hasan, A., 1994, Depletive water use project for regional water resource planning areas of New Jersey: Trenton, NJ, New Jersey Department of Environmental Protection, Appendix A-Depletive water use data, p. A33. 
For additional information, write to:

Director

U.S. Geological Survey

New Jersey Water Science Center

Mountain View Office Park

810 Bear Tavern Rd., Suite 206

West Trenton, NJ 08628

or visit our Web site at:

http://nj.usgs.gov/ 
